\title{
PAKó LÁsZló*
}

\section{GYILKOSSÁG A CSALÁDBAN. HALÁLOS KIMENETELÜ HÁZASTÁRSI KONFLIKTUSOK A KORA ÚJKORI KOLOZSVÁRON***}

\author{
Kulcsszavak: kora újkor, családi erőszak, házastársi gyilkosság/emberölés, mérge- \\ zés, bünüldözés
}

Az emberölés nem számított gyakori bűncselekménynek, súlyos következményei okán azonban mindig különleges figyelemben részesült. A társadalom számára minden egyes büncselekmény lehetséges veszélyforrás volt, de a tágabb vagy szúkebb közösségek, családok belső rendjére a pótolhatatlan emberéletet követelő tettek jelentették a legnagyobb veszélyt. E cselekmények a társadalom tagjaiban a létbizonytalanság érzését keltették, és az egyénnek az igazságszolgáltatásba vetett bizalmát rengették meg. Egy emberélet elvesztése amellett, hogy érzékenyen érintette egy család vagy egy kisebb közösség életét, veszélyt jelenthetett az ország és annak társadalma biztonságára is. Emiatt a hatóságoktól is, a társadalom minden tagjától is elvárták, hogy a bűnösök felelősségre vonásában részt vegyenek. ${ }^{1}$ A Szentírás „ne ölj!” parancsolatát már a Szent István király idejétől törvényeiben rögzítő magyar igazságszolgáltatás is mindig a legszigorúbban büntette e bűncselekmény elkövetőit.

Annak függvényében, hogy ki ellen irányult a tett, az emberölések több fajtáját különböztetjük meg. Írásunkban a házastársak - férj és feleség - egymás ellen elkövetett cselekményeit vesszük számba, melyek az emberi élet elleni bűncselekmények minősített esetei közé tartoznak. A kérdéskör jogi vonatkozásait csak érintőlegesen, a bűncselekmények társadalmi környezetét viszont, forrásadottságainkhoz igazodva, igyekszünk minél jobban kidomborítani, ezáltal pedig alaposabban körüljárni a kora újkori kolozsvári bűnözés egy kis, de a városi társadalomra jelentős kihatású szegmensét.

* Pakó László (1980), történész, Erdélyi Múzeum-Egyesület Kutatóintézete, Kolozsvár. E-mail: pako.laszlo@eme.ro.

** A tanulmány a Bolyai János Kutatási Ösztöndíj támogatásával készültt.

1 Vanessa McMahon: Gyilkosság Shakespeare Angliájában [Murder in Shakespeare’s England]. Magyar Könyvklub, Bp., 2005.12-13. 


\section{A KUTATÁS IDŐHATÁRAI, FORRÁSOK}

Nagyjából az 1570-1660-as évek közötti közel egy évszázad eseteit tekintjük át. Kutatásainknak a jelölt időszakra való korlátozását a forrásanyag mennyisége és feldolgozásának időigényessége követelte meg. Forrásaink minőségéből és mennyiségéből fakadóan, témánk egyes vetületeit alaposabban, másokat kevésbé részletesen, esetenként pedig csak sommásan tudtuk kidomborítani. Legfontosabb forrásunkat Kolozsvár város törvénykezési jegyzőkönyveinek a kötetei képezik. ${ }^{2} \mathrm{~A}$ sorozat az említett időszakra nem teljes, a nyolc évtizedből 28 év, azaz az időszak harmadának forrásai hiányoznak, ugyanakkor legtöbbször a többéves időközt átfogó egyes kötetek kezdő-, illetve záróévei is csonkultak. A kötetek tartalma sem egységes. A 16. századiak szinte kizárólag a perek során megszólított tanúk vallomásait, illetőleg ritkán a bíróság első- és/vagy másodfokú ítéleteit tartalmazzák. 1611-től a más permozzanatokat rögzítő feljegyzések is hangsúlyosabban megjelennek a kötetekben, az 1640-es évektől pedig e bejegyzések kerülnek túlsúlyba, teljesen kiszorítva a tanúvallomásokat. Mostani elemzésünk szempontjából ez azt jelenti, hogy a bủncselekmények társadalmi hátterének a vizsgálatához a 16. század végi és a 17. század eleji perek részletesebb adatokkal szolgálnak, a későbbiek inkább perjogi kérdések kidomborítására alkalmasak. A használt források tekintetében a városi számadások közül a városi jogügyigazgatók éves elszámolásainak sorozatát kell kiemelnünk. ${ }^{3} \mathrm{E}$ feljegyzésekben ugyanis a - mai kifejezéssel a városi föügyész jogkörét betöltő - két jogügyigazgató (direktorok, directores causarum) hivatalból indított perekkel kapcsolatos kiadásait rögzítette. $\mathrm{E}$ feljegyzésekből gyakran a perek számos mozzanatát megismerhetjük, és szerencsés esetben még a végkifejletről is értesülhetünk. Végül megemlítjük a városi kiadásokat és bevételeket kezelő sáfárpolgárok éves számadásait is, melyek ugyan ritkábban, de tartalmaznak adatokat a peres eljárás egyes mozzanatai - leginkább a bírósági ítéletek végrehajtása - során tett kiadásokról.

2 Lelőhelyük: A Román Nemzeti Levéltárak Kolozs Megyei Osztálya, Kolozsvár [Serviciul Județean Cluj al Arhivelor Naționale ale României, Cluj-Napoca] (a továbbiakban RNLtKol), Kolozsvár város levéltára [Primăria municipiului Cluj] (a továbbiakban KvLt), Törvénykezési jegyzőkönyvek [Protocoale de judecată] (a továbbiakban: KvTJk).

3 Tevékenységükról az eddigi legátfogóbb összefoglalást lásd László PAKó: Zur Rechtspflege und Vermögensverwaltung im Siebenbürgen des 16.-17. Jahrbunderts. Fiskaldirektoren im frübneuzeitlichen Klausenburg (1584-1660). Ungarn Jahrbuch. Zeitschrift für Interdisziplinäre Hungarologie 34(2018). 69-90. 


\section{TÖRVÉNYEK}

Már Szent István törvényei pénzbírsággal vagy halállal büntették a homicídiumot. ${ }^{4}$ Mátyás 1486. évi Decrétuma megkülönböztette a tettét előre eltökélt, aljas szándékkal (mens rea) elkövető gyilkost az emberölés más formáit elkövető bűnösöktől. Az előbbieknek rendi hovatartozásukra való tekintet nélkül kivégzés volt a büntetése, és megtiltotta a hozzátartozókkal való pénzbeli egyezkedést. ${ }^{5}$ 1495-től a törvények a negyedik rokonsági fokon belüli, azaz vérrokonok életét kioltókat a hủtlenség büntetésével sújtották. ${ }^{6}$ E szabályozások Werbőczy István Hârmaskönyvébe is bekerültek, ${ }^{7}$ és meghatározták az emberi élet elleni bủncselekmények elkövetôi elleni fellépést a kora újkor folyamán is. A törvényes előírások szerint tehát, aki szántszándékkal oltotta ki egy ember életét, társadalmi állására való tekintet nélkül halállal bünhődött, akinek esetében viszont a szándék kétséget kizáróan nem bizonyosodott be, az vérdíj lefizetésével menthette életét. ${ }^{8}$ Természetes, hogy ezeknek az elveknek a gyakorlatba ültetése számos egyedi megoldást szült.

\section{A CSALÁD A KORABELI FELFOGÁSBAN}

Minthogy a kora újkorban is a család, illetve a háztartás jelentette a rend alapját, a rendezett háztartások pedig az ország jólétét szavatolták, kiemelt hangsúlyt kapott a családtagok közötti kötelék fenntartása. Habár többen hangsúlyozzák, hogy a korábbi korok emberének hétköznapját a mainál erősebben átitatta a fizikai erőszak, amihez elfogadóbban is viszonyult, az emberölések azonban akkor sem illeszkedtek a normalitásról alkotott képbe. ${ }^{9}$ A korszak teoretikusai a családot a politikai hatalom, a társadalom és az egyház alapvető tartópillérének tekintették. Vallották, hogy elsősor-

4 1000-1526. évi törvényczikkek. Szerk. Nagy Gyula-Kolosvári Sándor-ÓvÁri KelemenMárkus Dezső. Franklin Társulat, Bp., 1899 (Magyar Törvénytár 1000-1895). 27, 29. Szent István király dekrétomainak második könyve, 14. fej. (feleséggyilkosokról), 16. fej. (szándékos emberölésről), 36. fej. (ha szolga szolgát öl), 46. fej. (akik karddal ölnek embert).

5 Uo. 447. - I. (Corvin) Mátyás, Hatodik decretum (1486), 51. cikkely.

6 Uo. 567. - II. Ulászló Második Decretuma (1495), IV. czikkely, 5. §.

7 Werböczy Istuán Hármaskönyve. Szerk. Kolosvári Sándor-Óvári Kelemen-Már Kus Dezső. Franklin Társulat, Bp., 1897 (Magyar Törvénytár 1000-1895). I. rész, 14. cím, 5. §.

8 Nem volt ez másképp Havasalföld 17-18. századi törvénykönyvei esetében sem, amelyek a közeli rokon életének a kioltását, a csecsemőgyilkosságot vagy a méreg használatát minősített bűncselekményként kezelték, és halállal büntették. Ligia LIVADĂ-CADESCHI-Laurenţiu VLAD: Departamentul de Cremenalion. Nemira, Buc., 2002. 16, 18.

9 J.A. Sharpe: Domestic Homicide in Early Modern England. The Historical Journal 24(1981). 1. sz. (a továbbiakban Sharpe: Domestic Homicide) 30-33; McMahon: i. m. 26, 135. 
ban a családban kell megteremteni és fenntartani a rendet, mert a család jó tagjai eséllyel válnak az országnak és az egyháznak is hüséges és jó tagjaivá. ${ }^{10}$

A házasság fogalmának és a házastársak egymáshoz való viszonyának, a házastársi rangsornak a kérdésében viszont már megoszlottak a vélemények. Ulinka Rublack találóan jegyezte meg, hogy „a házasság fogalmának középpontjában egy idült feszültség húzódott egyrészt a házastársak egyenrangúságát hirdető bajtársi, partneri eszmék, másrészt a patriarchális, azaz a férj elsőbbségét hangsúlyozó felfogás között”. ${ }^{11}$ Az utóbbi szerint, a középkori eszmékre épülő kora újkori gondolkodás nem a férj és feleség egyenjogúságán alapuló családmodellt ismerte. A családnak - egyesek megfogalmazásában, az ország politikai felépítését kicsiben leképző mikrokozmosznak - az államhoz hasonlóan megvolt a vezetője, a családfeje, aki erős kézzel irányította a háztartásában élőket. Neki a hatalmát tiszteletben kellett tartani, mert az engedetlen háztartások az állam alapjainak a megingásához vezethettek. ${ }^{12} \mathrm{~A}$ családnak a rend, az egység és a harmónia megtartása volt a feladata, ennek egyik legfőbb öszszetevőjét pedig a feleség engedelmessége és hűsége jelentette. ${ }^{13} \mathrm{~A}$ patriarchális társadalom nem nézte jó szemmel az ellenkező, lázadó, a férfiúi hatalom alól függetlenedni kívánó nőket, természetellenesnek találta az egyedülállóként élő asszonyokat. ${ }^{14}$ Vallották, hogy a gyengébb és ingatagabb természete miatt a különféle csábításokra fogékonyabb asszonyt férjének szoros felügyelet alatt kell tartania, akár fizikai erőszak árán is. ${ }^{15} \mathrm{~A}$ feleségre tehát mint férjének segítőjére, támogatójára tekintettek,

10 James Sharpe: A Fiery and Furious People. A History of Violence in England. Arrow Books, London, 2016 (a továbbiakban Sharpe: Fiery and Furious). 170.

11 Ulinka Rublack: The Crimes of Women in Early Modern Germany. Clarendon, Oxford, 1999. 197.

12 Sharpe: Fiery and Furious 170; Cissie Fairchilds: Women in Early Modern Europe, 15001700. Pearson Longman, Harlow, 2007. 7-8; Sara M. Butler: Violence and Murder in Europe $=$ The Cambridge World History of Violence. II. 500-1500 CE. Eds. Matthew S. Gordon-Richard W. Kaeuper-Harriet Zurndorfer. Cambridge University Press, Cambridge, 2020.335.

13 Marisha CAswell: Mothers, Wives and Killers. Marital Status and Homicide in London, 1674-1790 = Female Transgression in Early Modern Britain. Literary and Historical Explorations. Eds. Richard Hillmann-Pauline Ruberry-Blanc. Ashgate, Farnham, 2014. 118; Nancy Shields Kollmann: The Extremes of Patriarchy. Spousal Abuse and Murder in Early Modern Russia. Russian History 25(1998) (a továbbiakban SHields KollMANN: The Extremes of Patriarchy). 133-134.

14 Caswell: i. m. 119; Géra Eleonóra: Házasság Budán. Családtörténetek a török kiüzése után újjászülető (fö) városból, 1686-1726. MTA BTK TTI, Bp., 2019 (Magyar Családtörténetek. Tanulmányok 3). 50.

15 A középkori, gyakran félremagyarázott vallási tanításokra, a mai szemmel kezdetlegesnek számító orvosi ismeretekre és a korszak államhatalmi szolgálatban álló toretikusai véleményére alapuló meglátás szerint, az asszony a fegyelmezetlenség jelképe volt. Egy korabeli közmondás „hit, törvény, félelem és kitartás nélküli, tökéletlen bestiának” nevezte. Biológi- 
alárendelt szerepet szánva neki a családi rangsorban. ${ }^{16}$ John Locke, 17. századi filozófus és politikai gondolkodó megfogalmazásában, amint a köznép is lemond természetes döntési és cselekvési jogáról az országot irányítók javára, úgy a családban is a feleségnek le kell mondania döntési jogáról az erősebb és hozzáértőbb javára. ${ }^{17}$ Többen rávilágítottak, hogy a családon belüli szerepek megfordulását, azt a „feje tetejére állított világot”, melyben az asszony vette át az irányító szerepét, és amely a fennálló társadalmi rendet fenyegette, a kora újkori társadalom macskazene formájában gúnyolta ki. ${ }^{18} \mathrm{Az}$ a férfi, aki a felesége vagy háztartása más tagjai felett elveszítette az irányítást, a társadalmi helyzetének aláásását is kockáztatta. ${ }^{19}$ Pázmány Péter 1636ban egyenesen „eszefogyottaknak” nevezte azokat az özvegyeket, akik férjük halálát egy nehéz és szomorú igából való szabadulás örömével fogadták, „mert ha amely hajónak elveszett kormányosa, nem szabados, hanem puszta, és szelek hányására s habok rontására bízatott. Az asszonyember is, férjének gondviselése nélkül, minden nyavalyák habjaiban forog”. ${ }^{20}$ A kolozsvári bírák egy 1630 -as ítélete szerint, a fenti nézet a 17. század első felének városi ítélkezőitől sem volt idegen: „az asszonyállatnak

ai tényezőkkel magyarázták ezt: testfelépítésében a hideg és nedves testnedvek domináltak, amelyek változékony természetű, hủtlen és csalásra hajlamos tulajdonságaikat erősítették fel. Így az asszony természetét gyengébbnek és ingatagabbnak gondolták, akinek rossz tulajdonságai általában a jók fölé kerekedtek. E kiszámíthatatlan lénynek tanulásra nem fogékony, a politikai és vallási felelősségek alól felmentett és saját szenvedélyei által vakon vezérelt természete mindenkiben szorongást keltett, emiatt ítélték szükségesnek a férj hatalmának alárendelni őt. Margaret L. KInG: Femeia Renaşterii = Omul Renaşterii [L'uomo del Rinascimento]. Coord. Eugenio Garin. Polirom, Iaşi, 2000. 251; Natalie Zemon Davis: A nők felülkerekedése (a továbbiakban ZEMON DAvis: A nők) = Uő: Társadalom és kultúra a kora újkori Franciaországban. Balassi, Bp., 2001 (a továbbiakban ZEMON DAvis: Társadalom és kultúra). 117-120; Robert Muchembled: Pătimiri ale femeilor în vremea reginei Margot, 1553-1615 [Passions de femmes au temps de la Reigne Margot, 1553-1615]. Cartier, Chişinău, 2004.55-63; Joanne BAILEY: Unquiet Lives. Marriage and Marriage Breakdown in England, 1660-1800. Cambridge University Press, Cambridge, 2003. 111.

16 GÉRA: $i . m .51$.

17 Zemon Davis: $A$ nók 120.

18 Natalie Zemon Davis: A Rendetlenség kormányzatának rendszere = Zemon Davis: Társadalom és kultúra 110-111, 272-273; Zemon Davis: A nők 129-131; Sara F. MatThewsGrieco: Corp şi sexualitate in Europa Vechiului Regim = Istoria Corpului. I. De la Renaștere la Secolul Luminilor [Histoire du corps. I. De la Renaissance aux Lumières]. Coord. Georges Vigarello. Art, Buc., 2008. 212-213; Diane Hall-Elizabeth Malcolm: Sexual and Family Violence in Europe = The Cambridge World History of Violence. III. 1500-1800. Eds. Robert Antony-Stuart Carroll-Caroline Dodds Pennock. Cambridge University Press, Cambridge, 2020.279.

19 Hall-Malcolm: i. m. 276.

20 Pázmány Péter: A keresztyén özvegyasszony tüköre = Pázmány Péter müvei. Vál., szöveggondozás, jegyz. Tarnóc Márton. Szépirodalmi, Bp., 1983. 641; Géra: i. m. 50-51. 
feje az ő férje, és az közönséges jóknak is gondviselése azt illeti, az asszonyállat penig nemhogy az jókkal, de magával is nem szabados". ${ }^{21}$

A fenti elképzelést lényegesen átformálta azonban a humanista hagyomány térnyerése, a reformáció hatása és a katolikus nézőpont változása is. Habár a családi rangsor, benne a családfő elsőbbsége továbbra sem képezte vita tárgyát, de a család fejétől nem azt várták, hogy önhatalmúlag és erőszakkal irányítsa családja életét, hanem egy olyan ,jó fejedelem” mintájára tegye, aki becsületes, okos és következetes kormányzással hoz békét és jólétet alattvalóira. A feleség férje segítője helyett annak társává lépett elő, aki a családi élet bizonyos területeit önállóan felügyelte: ő volt az otthon vezetője, az utódok és szolgálók irányítója és a családi készletek őrzője. A házastársakra olyan részekként tekintettek, melyek együtt alkothattak egy teljes egészet. ${ }^{22}$ Egy rendezett egyenlőség kialakítása tarthatta csak fenn a családot abban a korban, amikor - mivel a család volt a termelés alapegysége - a földmúves vagy a kézmúves életforma mindkét fél egyenlő részvételét követelte abban a mindennapi, nem csak háztáji tevékenységekben kimerülő munkában, amely a család és a háztartás fenntartását eredményezte. A közös munkán, az egyetértésen, az egymás iránti kölcsönös gondoskodáson és tiszteleten alapuló partneri, bajtársi kapcsolatnak utat kellett tehát találnia magának a kora újkori emberek mindennapjaiba, mert a gazdasági túlélés elengedhetetlen kelléke volt a házastársak közötti kölcsönös együttmúködés és megbecsülés. ${ }^{23}$

\section{ERÔSZAK A CSALÁDBAN}

Mivel azonban az elvárás és a gyakorlat között soha nincs teljes átfedés, a kora újkori rendezett családi egyenlőség elérése is számos akadályba ütközött. A fentiekben vázolt, a házastársak közötti partneri viszonynak a kialakulását elsősorban a gazdasági okok ugyan elősegítették, de a jogi szabályozások már nem igazodtak az új helyzethez, ez pedig számos nézeteltéréshez vezetett. ${ }^{24} \mathrm{E}$ tekintetben a kutatás számára sem vitás, hogy számos kora újkori család tagja szembesült bizonyos szintú családon belüli erőszakkal. Esetenként ugyanakkor ez olyan méreteket is ölthetett, hogy a rendezett házastársi kapcsolat már nem állhatott helyre.

21 KvTJk II/13. 173.

22 GÉRA: i.m. 51-52.

23 Rublack: i. m. 198; Steven Ozment: When Fathers Ruled. Family Life in Reformation Europe. Harvard University Press, Cambridge, Massachusetts and London, 1983. 50-72, 99; Uó: Ancestors. The Loving Family in Old Europe. Harvard University Press, Cambridge, London, 2001. 36-38; Fairchilds: i. m. 3-4; Hall-Malcolm: i. m. 275-276, 279.

24 GÉrA: i. m. 53. 
Az erdélyi unitárius egyház Kolozs-Dobokai egyházkörének ítélőszéke például a 16. század végén több olyan férfit, köztük kolozsváriakat is elválasztott a feleségétől, akik szidalmazták, otthonukból elűzték, éheztették, fizikailag bántalmazták beteg vagy akár terhes feleségüket, magzatvesztést is okozva nekik. Mások egyenesen halállal, feldarabolással és ebek elé dobással, fojtással vagy szemkivájással fenyegették asszonyukat. Ritkábban női bántalmazókkal is találkozunk. Egy kolozsvári asszonyt például azért választottak el férjétől, mert nem tisztelte és becsülte asszonyhoz méltóan férjét, nem teljesítette házassági kötelességeit, tékozolta férje vagyonát, szidta és verte urát, kirekesztette a szállásáról, nem hált vele egy ágyban, házasságtörés gyanújába is keveredett..$^{25}$ De a $18-19$. századi Debrecenből is számos példát ismerünk feleségüket brutális kínzásoknak alávető férfiakról. ${ }^{26}$

Egy olyan korszakban azonban, ahol válással csak viszonylag kevesek szabadulhattak a nem kívánt házasságból, ${ }^{27}$ a házastársak kerülhettek olyan, látszatra kiút nélküli helyzetbe - James Sharpe megfogalmazásában: „társadalmi és érzelmi csapdába" -, amelyből az egyetlen, gyors és biztos menekvést a házastárs fizikai megsemmisítésében láthatták. S ha a férjnek vagy saját felségterületén az asszonynak, a háznépe feletti jogos - azaz nem harag által motivált és komoly fizikai sérülést sem okozó - fenyítő hatalmába beleillő fizikai bántalmazás elfogadott is volt ${ }^{28}$ a házastárs életének kioltását eredményező túlzott erőszakot a teológiai, a jogi és a humanista diskurzus egyaránt elutasította. ${ }^{29}$ Egy, a 17-18. századi lengyel vidéki társadalom pár-

25 Az Erdélyi Unitárius Egyház Gyűjtőlevéltára, Kolozsvár, a Kolozs-Dobokai egyházkör parciális zsinati jegyzőkönyve, 1587-1606 (a továbbiakban Parciális zsinati jegyzőkönyv). 21, 25-27, 49-51, 55-56, 90-91, 118-119, 186-187, 195-196, 199, 231-234. A férjeiket bántalmazó asszonyok eseteit lásd uo. 160-161, 211-212.

26 Mátay Mónika: Törvényszéki játszmák: válás Debrecenben 1793-1848. Csokonai, Debrecen, 2006. 232-235.

27 Roderick Phillips: Amit Isten összekötött... A válás rövid története. Osiris, Bp., 2004. 17-50.

28 Hall-Malcolm: i. m. 276. E tekintetben idézzük egy válási ügy 1592. januári ítéletét, melyben az érintett férj ráadásul unitárius prédikátor volt: „Meg volt penig írva az composicional levélben, hogy Clemens Salinus mód nélkül, ok nélkül az ő feleségétt, széki Gombos Annát ne verje, ne rongállja. Az bizonságok penig behozták, hogy ok nélkül nem verte meg az incamattus ez felljül megnevezett Gombos Annát, hanem az ő rebellis és contumax voltáértt.” Parciális zsinati jegyzőkönyv 20. Egy 1593. áprilisi ítéletében is azt hangsúlyozta a szentszék, hogy „mikor egyszer megverte, megteccik mind az kettőnek vallásából, hogy okot adott az asszony reá, azért ha valamikor egyébkor essett volna is az veresség rajta, ítélhettjük, hogy nem ok né[1]kül essett volna...”Uo. 47.1600 augusztusában egy házastársak közötti egyezségben azt kötötték ki a férfinak, hogy hallgassa a prédikációkat, és tanuljon belőlük, feleségét ne szidja fertelmes szitkokkal, ne gyalázza orvnak, házától ne űzze el, és ok nélkül ne verje meg. Tehát megtehette, ha volt oka rá! Uo. 242.

29 Susan Dwyer Amussen: 'Being Stirred to Much Unquietness'. Violence and Domestic Violence in Early Modern England. Journal of Women's History 6(1994).71-72; Madeleine LAzARD: Eva în oglindă. Viaţa femeii în Renaştere [Les avenues de Fèmynie. Les Femmes et la 
kapcsolatait és házasodási szokásait vizsgáló elemzés ugyanakkor figyelmeztet, hogy esetenként a még jogosnak és mérsékeltnek ítélt fenyítések is igencsak brutális, akár a sértett öngyilkosságához is vezető fizikai bántalmazásokat jelenthettek. ${ }^{30} \mathrm{~A} 17$. század első felének németalföldi jogtudósa, Hugo Grotius is azt hangsúlyozta, hogy jogilag a férjek hatalma ugyan kiterjedt feleségükre, de aki visszaélt e hatalmával, és kegyetlenül bánt házastársával, pénzbeli, tettének ismétlődése esetén pedig jóval szigorúbb büntetésre számíthatott. ${ }^{31}$ Adódtak továbbá olyan esetek is, amikor az egyik fél nem(csak) a családi erőszak elől menekülve, hanem egy új kezdet reményében próbált helyet csinálni háztartásában egy másik, őt érzelmi, testi vagy anyagi szempontból jobban kielégítő személynek. Minthogy sem az egyház, sem az állam nem kínált túl sok lehetőséget erre, így a tetteseknek esetenként a legradikálisabb megoldás, a házastárs életének a kioltása tûnhetett járható útnak. ${ }^{32}$

Kolozsváron a vizsgált időszakból hét olyan pernek az anyaga maradt fenn, melyben a vádlottakat házastársuk életének a kioltása, arra tett kísérlet vagy házastárs elleni gyilkosságra való felbujtás miatt állítottak bíróság elé.

\section{MÉREGGEL A HÁZASTÁRS ÉLETE ELLEN}

A fent említett esetek közül háromban a méreg volt a gyilkos fegyver. Ha valaki méreggel oltott ki emberéletet, mindenki számára nyilvánvaló volt, hogy tette előzetes gonosz akarattal kitervelt szándékos gyilkosság és nem önvédelem, véletlen vagy hirtelen felindulásban elkövetett emberölés volt. Már akkor is aljas, iszonyatos, undorító, gyúlöletes és rettegett gyilkossági módnak tartották, mert a tettre az áldozat tudtán kívül, közvetlen összetűzés nélkül került sor, így nem volt megelőzhető, és fizikai erőre sem volt szükség elkövetéséhez. Érthető tehát, hogy a méregre a fizikailag

Renaissance]. Saeculum, Buc., 2007. 50-51, 54-55; McMAноn: i. m. 135-144, 155-156, 165; Muchembled: i. m. 62-63, 138, 152; Sharpe: Domestic Homicide 45; King: i. m. 251; Rublack: i. m. 197-200, 224; Pieter Spierenburg: A History of Murder. Personal Violence in Europe from the Middle Ages to the Present. Polity, Cambridge, 2008. 135; Dorothea Nolde: The Language of Violence. Symbolic Body Parts in Marital Conflicts in Early Modern France $=$ Violence in Europe. Historical and Contemporary Perspectives. Eds. Sophie BodyGendrot-Pieter Spieren burg. Springer, New York, 2008.143-145; Géra: i. m. 135-136.

30 Tomasz Wislicz: Love in the Field. Relationships and Marriage in Rural Poland in the Early Modern Age: Social Imagery and Personal Experience. Tadeusz Manteuffel Institute of History, Polish Academy of Sciences, Warsaw, 2018. 143-144.

31 Manon van der Heijden: Women as Victims of Sexual and Domestic Violence in SeventeenthCentury Holland. Criminal Cases of Rape, Incest, and Maltreatment in Rotterdam and Delft. Journal of Social History 33(2000). 3. sz. 633; Uó: Women and Crime in Early Modern Holland. Leiden/Boston, Brill, 2016 (a továbbiakban Hejjden: Women and Crime). 153.

Rublack: i.m. 224. 
gyengébb vagy a hatalmi ranglétrán alulmaradt személyek alattomos fegyvereként tekintettek. Habár nem tükrözte a valóságot, de az volt az elterjedt nézet, hogy a gyilkosok közül a nők gyakrabban használták a mérget, mint a férfiak. ${ }^{33} \mathrm{~A}$ házastársak közül leginkább a feleségeket gyanúsították e tett elkövetésével, akik a korszak társadalmi elvárásainak megfelelően szúkre szabott, a családfő személye körül forgó mozgásterüket próbálták ezáltal némiképp tágítani. ${ }^{34} \mathrm{~A}$ korszak felfogása szerint a mérgezés a házastársak közötti bizalomnak a megsértését és a házastársi hűséggel, felelősséggel és kötelezettségekkel való visszaélést jelentette. A feleség nemcsak alattomos tettet követett el, hanem egyenesen elárulta férjét és családját, ugyanis visszaélve a háztartásban betöltött szerepével - ő lévén felelős családjának élelmezéséért -, annak életét oltotta ki, aki tőle gondoskodást, vigasztalást, segítséget várt, és aki a táplálkozás tekintetében teljesen rábízta magát. ${ }^{35} \mathrm{~A}$ nő tehát férjének megmérgezésével legfőbb családi kötelességét tagadta meg, azt, hogy házastársának ellátásáról és jólétéről gondoskodjék. Tettében így a hidegvérű gyilkosság és a feljebbvaló elárulásának vétke egyszerre volt jelen. A korszak felfogásában a férj meggyilkolása természetellenesebbnek hatott, mint a feleségé, mert nemcsak megzavarta a társadalmi rendet, hanem meg is fordította azt. ${ }^{36}$

1629 második feléből két előkelő városi polgár, Olajos Szabó János, városi százférfi (centumvir) és felesége, Géci István, szintén centumvir, Katalin nevű lánya közötti

33 Martin Randall: Women, Murder, and Equity in Early Modern England. Routledge, New York-London, 2008. 124.

34 David M. Turner: Fashioning Adultery. Gender, Sex and Civility in England, 1660-1740. Cambridge University Press, Cambridge, 2002. 124; Elizabeth Foyster: Marital Violence. An English Family History, 1660-1857. Cambridge University Press, Cambridge, 2005. 106; McMahon: i. m. 190-192.

35 Garthine Walker: Crime, Gender and Social Order in Early Modern England. Cambridge University Press, Cambridge, 2003. 144-148; Turner: i. m. 124; BaIley: i. m. 82; Frances E. Dolan: Home-Rebels and House-Traitors. Murderous Wives in Early Modern England. Yale Journal of Law and the Humanities 4(1992). 1. sz. (a továbbiakban Dolan: HomeRebels) 9; Uő: Dangerous Familiars. Representations of Domestic Crime in England, 1550 1700. Cornell University Press, Ithaca, 1994 (a továbbiakban Dolan: Dangerous Familiars). 29-30; Alastair Bellany: Thinking with Poison = The Oxford Handbook of the Age of Shakespeare. Ed. Malcolm Smuts. Oxford University Press, Oxford, 2016. 559-561. - Az angol kora újkori népi irodalom családi erőszakkal kapcsolatos eseteinek vizsgálata azt mutatja, hogy a 17. század közepéig a családi rend megbontásával kapcsolatos félelmek központjában a férje hatalma ellen lázadó, azt megdönteni próbáló feleség (alattvaló) alakja állt, és csak a század közepétől jelent meg a családjának tagjai felett zsarnokoskodó, akaratát arra rákényszerítő, felelőtlen, gyakran őrült férjnek is az alakja, aki erőszakos tetteivel szintén a családi béke megbontójává válhatott. Dolan: Dangerous Familiars 119; Dolan: HomeRebels 7-8; Dwyer Amussen: i. m. 75-76.

36 Nolde: i.m. 149. 
perről vannak adataink. ${ }^{37} \mathrm{~A}$ férj az asszonyt házasságtöréssel, házasságuk hưtlen elhagyásával, magzatvesztéssel és férjének megmérgezésére tett kísérlettel vádolta. A per anyaga töredékes, az elsőfokú itélet kihirdetése előtt kapcsolódhatunk be a történetbe. Habár az asszony tagadta a vádakat, a férfi pedig nem tudott minden kétséget kizáró bizonyítékokat felhozni ellene, az első fokon ítélkező városi bírák mégis csak akkor voltak hajlandók felmenteni az asszonyt a vádak alól, ha három becsületes hírú és állapotú eskütárssal együtt megesküszik ártatlanságáról. Megítélésük szerint ugyanis alapos volt a gyanú, hogy az alperes „urához való kötelessége ellen cselekedett volna”. A fellebbezést követően újabb tanúvallatásokra került sor. A felperes tanúi szerint az asszony éjjel Váradi Istvánné házához ment, ahol az asszony fiaival paráználkodott. A felperes több családtagja látta a házhoz érkező asszonyt, oda is rendelték a fertálykapitányt, de nem találtak senkit a helyszínen. E tanúk az esetleges mérgezés körülményeiről nem árultak el jóformán semmit. Két tanú hallomásból értesült az esetről, egy harmadiktól ugyan az alperes egy alkalommal megpróbált higanyt szerezni, de nem derült ki, hogy mi célból. Ezzel szemben az alperes több tanúja azt hangsúlyozta, hogy a vádak csupán a férj „csinálmányai” voltak, és hogy az egész egy megrendezett színjáték volt, melynek során a férj mentének való posztó ajándékozásával győzte meg például egyik rokonát, hogy vegyen részt benne, és segítsen neki, hogy „gyalázatot ejthessen a feleségén”. Perdöntő bizonyíték továbbra sem került elő, ennek ellenére a másodfokon ítélkező esküdt polgárok az eskütársak számát hatra emelték. A gyanú tehát fokozódott bennük az asszony bűnösségével kapcsolatban. Ố azonban letette az esküt, és megmenekült a vádak alól.

Arra tehát nem kapunk választ, hogy a mérgezés vagy annak kísérlete valóban megtörtént-e, az viszont nyilvánvaló, hogy a diskurzus, melyben a házasságtörés, magzatvesztés és mérgezés is szóba jött, egy ellentétekkel terhelt házassági kapcsolatról árulkodik. Ha a mérgezésre valóban sor került, akkor az asszony volt, aki e köteléket fel próbálta bontani. Adatok hiányában az azonban továbbra sem világos, hogy döntését a férj erőszakos viselkedése előli menekülés szándéka vagy esetleg egy új szeretőhöz való pártolásának vonzó érzelmi vagy anyagi kilátása motiválta volna. Az ítéletek viszont azt valószínúsítik, hogy a bírák hajlottak arra, hogy az asszony tettei mögött férje iránti házastársi kötelességeinek a megtagadását lássák. Ha viszont mégis a férfi vádolta alaptalanul mérgezéssel (is) feleségét azért, hogy tőle megszabadulhasson, akkor ő a mérgezésnek a vádpontok közé emelésével vélhetően azt a - korszak gondolkodását meghatározó - nézetet próbálta saját hasznára fordítani, miszerint a méreg azon nők, feleségek alattomos fegyvere volt, akik a korban bevett családi, hierarchikus kapcsolatok ellen lázadtak, és ezáltal nemcsak szúkebb családi környezetük, hanem tágabb városi közösségük belső rendjét is veszélyeztették. Ez

37 KvTJk II/12.108-115, 109a-b, 116, 123-124, 177a-b, 187, 191-192, 193, 196. 
esetben tehát ő akart hamis vádakkal szabadulni feleségétől, de az adatok az ô esetében sem árulkodnak pontosabb indítékokról.

1643-ból származik egy másik mérgezéses eset. ${ }^{38} \mathrm{~A}$ város jogügyigazgatói törvény elé állították a városban szolgáló, de idegen származású Bakos Varga Mártont. A vád szerint a legény titkos szerelmi kapcsolatba bonyolódott gazdájának, Szénégető Lőrincnek a feleségével, akivel „gonoszul élvén és conspirálván”, megmérgezték a férfit, majd a településről idegenbe szöktek, és összeházasodtak. Forrásaink töredékesek, emiatt az ügyről nem tudunk meg további részleteket. Nem tudjuk például, hogy hogyan került a férfi a törvény kezére, hogy mi történt az asszonnyal, mint ahogy azt sem, hogy az asszony egy összetúzésektől terhelt házasságból próbált szabadulni, vagy a legény melletti jobb élet ígérete, esetleg mindkettő késztette-e őt erre a cselekedetre. Arra viszont rávilágít az eset, hogy az a korabeli viszonyok között gyakorinak számító körülmény, hogy a háztartásokhoz nemcsak a szúk család tagjai, hanem a szolgák és a céhes legények is szorosan hozzátartoztak, ${ }^{39}$ számos kihívás elé állította a házastársak kapcsolatát, és számos viszályra adott okot. A szakirodalom is hangsúlyozza, hogy a házasságból menekülő asszonyok számára gyakran a háztartásban éló inassal, szolgálóval való egybekelés tűnt a legkézenfekvőbbnek. Mivel ezek jól ismerték a család hétköznapi tevékenységét, zökkenőmentesen át tudták venni annak irányítását, így a termelési folyamatba való bekapcsolódásuk is könnyen ment, egyből a kieső családfố szerepébe tudtak lépni. ${ }^{40}$

A fenti esetekben a férjek váltak mérgezés célpontjává vagy áldozatává, de adódott olyan eset is, amikor - az általános vélekedéssel ellentétben - a férj tört méreggel felesége életére. ${ }^{41} \mathrm{~A}$ társadalmi berögződések miatt a korabeli általános vélekedés az volt, hogy méreggel a fizikailag gyengébb és a családban kisebb mozgástérrel és hatalommal rendelkező feleségek támadtak házastársuk életére. A hidegvérrel, előre eltervezett, gonosz szándékkal, rejtőzködve végrehajtott tetteket többnyire a feleség személyéhez kapcsolták. A feleségük életére törő férjek s általában az emberéletre támadó férfiak esetében leginkább erőszakos, durva, hirtelen felindulásból, nyilvánosan és az éppen kézügyben található fegyverrel (baltával, késsel stb.) elkövetett tettekre számítottak. A kor felfogásában ez a cselekvési mód illett a férfiúi természet-

38 KvTJk II/15. 319, 320; RNLtKol, KvLt, Számadáskönyvek [Socoteli] (a továbbiakban KvSzám) 24/IV. 363-364.

39 James Sharpe szerint a 17-18. században az angliai munkaképes lakosság 80\%-a életének legalább egy szakaszát más háztartásban töltötte szolgaként, a 14-20 éves angliai fiúk 40\%-a pedig otthonától távol, szolgaként tevékenykedett. SHARPE: A Fiery and Furious 171.

40 RuвLAск: i.m. 224.

41 Az alábbi részről részletesebben lásd PAкó László: Gondos férj vagy feleséggyilkos? Mérgezésrôll, vérbajról és egy prókátori életút részleteiröl a kora ujjkori Kolozsváron. Erdélyi Múzeum LXXXII(2020). 1. sz. 65-82. 
hez. ${ }^{42} \mathrm{E}$ felfogásnak köszönhetően a férjekről ritkán feltételezték, hogy méreggel törnének feleségük életére. Pedig a kora újkori Európa számos vidékének példái mutatják, hogy valójában ők is éppen olyan gyakran próbálkozhattak házastársaik megmérgezésével, mint fordítva. Sőt, gyakrabban gyanúsították meg őket ilyen tettekkel, mint feleségeiket. ${ }^{43}$ Egyesek szerint a 17. századi Angliában a méreggel gyilkoló férjek száma kétszer, akár háromszor is akkora lehetett, mint a méreggel gyilkoló feleségeké. ${ }^{44}$

Számos olyan esetet ismerünk, amikor férfiak méreggel végeztek házastársaikkal. ${ }^{45}$ Ők azonban gyakran másként használták e fegyvert: fenyegették feleségeiket méreggel, személyesen hajtották végre tetteiket, a méreg hatásáról a tett helyszínén próbáltak tudomást szerezni. Lényegében tehát nem teljes titokban és észrevétlenül, hanem családjuk előtt, nyilvánosabban és hidegvérrel cselekedtek, ezzel is bizonyítva családfő́i hatalmukat. Tetteiket gyakran megkönnyítette az asszonyoknak férjük iránt táplált bizalma is. E bizalom okán ugyanis férjük kérésére olyasmit is megtettek orvosságok bevétele, gyógykezelések vállalása -, amit idegen tanácsára elutasítottak volna. Arra viszont vigyáztak a családfők, hogy tetteikről a külvilág ne szerezzen tudomást. Így ugyanis, ha bíróság elé is került ügyük, szemtanú hiányában ellenük csak olyan tanúk vallomásai szólhattak, akik hallomásból szerezték értesüléseiket, azok bizonyító erejét pedig könnyebb volt kétségbe vonni. Különösen akkor, ha a férj a közösség szemében végig a tisztességes férfi és törődő családapa szerepében mutatkozott. $^{46}$

Az általunk vizsgált kolozsvári anyagban egy olyan pert találtunk, melyben férfit gyanúsítottak feleségének megmérgezésével. Igyártó György prókátor és Kolozsvár 1580-as évekbeli hírhedt boszorkányüldözője 1581-ben perbe idézte Rengő Annát, mert az asszony farsang idején férfiruhában jelent meg a város utcáin, és zavarta meg tettével - legalábbis a prókátor szerint - a város erkölcsi tisztaságát. Minthogy nem először került Igyártó vádjainak kereszttüzébe, az asszony ellentámadásba lendült, és egyebek mellett azzal vádolta meg a prókátort, hogy első feleségét megmérgezte, hogy tôle megszabadulva, azzal házasodhasson össze, akivel tiltott szerelmi viszonyban volt, és aki titkon gyereket is szült neki. A vallomásokból kirajzolódó vádak alapján, a férfi beteges első feleségének rendszeresen higanyt tartalmazó kenőcsöket és italokat adott, egy borbély ajánlására indokolatlanul kockázatos kezelést, pároltatás-

42 McMahon: i. m. 196-197, 202-203; Spierenburg: i. m. 128.

43 Foyster: i. m. 106; Bailey: i. m. 82; McMahon: i. m. 203. Az itáliai Bologna és Ferrara példái is ugyanezt bizonyítják. Alessandro Pastore: Poison and Poisoning in Renaissance Italy $=$ Murder in Renaissance Italy. Eds. Trevor DeAN-K.J. P. Lowe. Cambridge University Press, Cambridge, 2017. 228, 235-236, 242.

44 Dolan: Dangerous Familiars 89.

45 Turner: i.m. 124.

46 Dolan: Dangerous Familiars 100, 102; McMahon: i. m. 205-206. 
sal egybekötött fürdôt csináltatott neki, és mérgezett hallal is táplálta. Mi több, egy népi gyógyító közbenjárását is kérte felesége megmérgezése érdekében. Az asszony többször hangoztatta, hogy tartott férje gyilkos szándékától, és állította, hogy férjétől való félelmében többször volt kénytelen mérgezett italt fogyasztani. A házaspár két lánya is az apa ellen vallott. Egyikük meg volt győződve, hogy az apja által erőltetett gyógykezelés lett anyja végzete, a másik pedig azt hangoztatta, hogy a hosszú időn keresztül adagolt higany miatt, „ha most felásnák az anyámat, tehát ugyan tudom, hogy kettéhasadva találnák". Az egyik szerint a házaspár harmadik gyermeke, egy fiú, tudott apja szándékáról, de új ruhák ígérete miatt, hallgatott. A prókátor tanúi azonban cáfolták a fenti vádakat. Szerintük az asszony vérbajban szenvedett, s habár férje minden igyekezetével feleségének gyógyításán fáradozott - a higanyt sem mérgezés, hanem gyógyítás szándékával adta az asszonynak -, a kór végzett az asszonnyal.

Mivel forrásaink ez esetben is hiányosak, nem ismerjük az ügy végét, ennek ellenére levonhatunk néhány tanulságot témánk szempontjából. Ha Rengő Anna álláspontjának hitelt adunk, akkor az ügy több részlete illeszkedik a korszak más hasonló esetei alapján fentebb már ismertetett képbe, amikor a férj előre kitervelt módon szabadult meg házastársától. Tudatosan választotta ki a gyilkosság módját és idejét, ugyanis az asszony betegsége tökéletes alkalom volt arra, hogy gyógykezelésnek álcázva, lassan, halálos mennyiségú higanyt juttasson a szervezetébe. ${ }^{47}$ Ugyanakkor felesége halálát is könnyen írhatta a kezelés elégtelenségének számlájára. Mint családfő, ő döntött felesége gyógykezelésének kérdéseiben, és nem türt beleszólást döntéseibe. Családtagjai előtt sem titkolta különösebben tettét, hiszen fia tudott tervéról, és lányai is gyanították apjuk szándékát. Idegen viszont nem szerzett közvetlen tudomást róla. A bíróság elôtt pedig vélhetően elismert prókátori hírnevére, illetve a szakmai tevékenysége során a tanúk és a bírák nézeteinek befolyásolásában szerzett tapasztalataira támaszkodva sikerült saját igazának érvényt szereznie. Ez azért is múködhetett, mert a döntés során a bíráknak egyfelől egy szakmailag elismert városi tisztségviselő, másfelől az igazságszolgáltatással többször ütköző, laza erkölcsű aszszony állításai között kellett választaniuk. S abban a világban, ahol a nemek közötti egyenlőség elve nem érvényesült, nem meglepő, ha Igyártó és nem Rengő Anna állításait fogadták el.

47 A szakirodalom is hangsúlyozza, hogy a feleség betegségének vagy a szülésnek az időszakában, amikor átmenetileg kézbe vehették a háztartás irányítását, a férfiak könnyebben mérgezhették meg feleségüket. Spierenburg: i. m. 130. 


\section{HALÁLT OKOZÓ NYÍLT ERŐSZAK A HÁZASTÁRS ELLEN}

A titokban vagy alattomban elkövetett mérgezések mellett találkozunk olyan esetekkel is, melyekben a bűncselekmény elkövetése fizikai erő, durva és nyers erőszak nyilvános alkalmazásával járt, melyekben gyakran külső tényezők - harag, hirtelen felindulás, alkoholfogyasztás - befolyásolták az események lefolyását. Ebből fakadóan a tettesek is általában a férfiak sorából kerültek ki.

1584-ben a Kolozsvár melletti Papfalva oficiálisa a város bírósága elé idézte a szintén papfalvi Illés Jánost, akit vérfertőzéssel és egyéb fertelmességekkel vádolt.. ${ }^{48} \mathrm{~A}$ fennmaradt egyetlen tanúvallomás egy olyan család életébe ad betekintést, melyet a családtagjaival sorozatosan kegyetlenkedő férj uralt. A tanú a házaspár leánygyermeke volt, akinek szavai szerint, egy alkalommal, mikor anyja Kolozsváron tartózkodott, apja részegen tért haza a kocsmából, megerőszakolta őt, majd torkának szegezett késsel kényszerítette hallgatásra. Apja fenyegetései ellenére, a gyermek beszámolt anyjának a történtekről. Az asszony viszont hallgatásra intette őt, az alkohol hatásának tulajdonította az apa viselkedését, nyugtatta a lányt, hogy nem kell tartania a tett megismétlődésétől. Egy idő múlva azonban apja magával vitte a lányt az erdőre, ahol egy fához szorítva újra megerőszakolta. Egy kocsmai mulatozást követően harmadszor is bántalmazta a lányát az apa. Miután ugyanis éjféltájban néhány román társaságában hazatért a kocsmából, kísérői szeme láttára úgy elverte feleségét, hogy az asszony néhány nap múlva belehalt a fején szerzett sérüléseibe. Lányával is oly kegyetlenül elbánt, hogy maguk az ivócimborák kérték az asszonyt, hogy: „vidd el gyermekedet, mert iszonyú parázna ember a te urad, tüzet érdemel!” Anyja halálát követően a lány többször jelentette a városi esküdt polgároknak apja erőszakoskodásait, majd Bácsba, onnan pedig Monostorra menekült zaklatásai elől. Vallomásában azt is előadta, hogy az ő távozása után apja két rokonával is paráználkodott, mindkettő terhes maradt, és mindkét gyermeket nyomtalanul eltüntette a férfi.

További adataink nincsenek a perről, az eset azonban rámutat arra, hogy a korszak gondolkodásában a házastársak viszonya tekintetében végbemenő, fentebb említett változások ellenére egy-egy kora újkori család élete, tagjainak biztonsága és jóléte mennyire ki volt szolgáltatva a családfó hatalmának. A férj, akinek összeférhetetlen természetét ivócimborái is elítélték, önhatalmúlag rendelkezett családja tagjai fölött, tekintélyének sem kívülállók, sem háztartásának tagjai nem szabhattak határt. Felesége pedig a gyereknevelés és a háztartás mindennapi feladatainak az irányítása mellett kénytelen volt eltürni férje kegyetlenkedéseit is. Habár házasságban éltek, mindkettőnek megvolt a maga külön világa, a férfinak a kocsma más férfiakkal, az asszonynak pedig az otthona a gyerekkel és a gazdasággal, a két világ között pedig alig

48 KvTJk II/7.305. 
létezett átfedés. Az eset rámutat az alkoholfogyasztásnak a családi életre gyakorolt káros hatására is, ugyanis a házastársak közötti hasonló összetűzésekre gyakran olyankor került sor, amikor az asszony felemelte a szavát a férj ivással és az iváshoz kapcsolódó rossz szokásaival kapcsolatban. Ezt pedig a férjek általában családi hatalmuk és tekintélyük kétségbe vonásaként értelmezték, és keményen felléptek annak védelmében. ${ }^{49}$

1630-1631 folyamán Kolozsvár jogügyigazgatói Szebeni Mihály kolozsvári mészárosmester ellen pereltek, aki Szappan utcai házuknál, „hátrahagyva Istennek törvényét és az házasságbeli kötelességet és szeretet[et]”, csákányával úgy fejbe ütötte feleségét, hogy az asszony belehalt sérüléseibe. ${ }^{50} \mathrm{~A}$ tanúk szerint a gyerekével az ölében és egy mészárosinas társaságában a tüzhelynél ülő asszonyra a hazaérkező férfi minden figyelmeztetés nélkül támadt rá. A vádlók Werbőczy István Hármaskönyvére hivatkozva a tettest mint hủtlenség bünébe esett személyt „fején, jószágán kévánnják convincáltatni”, azaz a fej- és jószágvesztés büntetését kérték rá. Az alperes vitatta a jogügyigazgatók mint közvádlók fellépésének jogosságát, szerinte ugyanis az áldozat atyjafiainak kellett volna perelni. A direktorok azonban másként vélekedtek: „a te factumod oly enorme vitium, s oly nagy vétek, hogy te az atyafiakkal sem békélhetel meg az communitas ellen, mert ez az egész communitast is nézi. Ha reád bizonyultatik, hogy illyen nagy vétek, megbüntettessék". A vádlott beismerte, hogy hirtelen haragjában valóban megütötte feleségét csákánya nyelével, de szerinte ütése csak kisebb sebet ejtett az asszonyon. Azt hangoztatta, hogy a halál igazi oka gutaütés lehetett, melyet a piacon áruló asszony halétel által okozott csömörtől kapott. Egyes tanúk szerint, a férfi őszintén bánta hirtelen felindulásból elkövetett tettét. Minthogy az asszony sebének gyógyításán fáradozó borbélyok egyetértettek abban, hogy az asszony halálát a keletkezett sebek okozták, továbbá mivel a vádlott nem tudta igazolni, hogy tette csupán a véletlen múve volt, a bírák szándékos emberölés gyanújával fejvesztésre ítélték ôt. A tettes fellebbezett, és egy levelet is felmutatott saját védelmében, melyben a fejedelem az ügyről személyes felvilágosítást kért. A városbírák jóváhagyták a fellebbezést, a folytatásról azonban nincsenek adataink.

A források nem árulják el, hogy a tettet az asszonyt a tüz mellett egy inassal együtt találó férjben egy vélt házasságtörés gyanúja miatt hirtelen fellángoló düh vagy féltékenység, esetleg más ok váltotta-e ki. Azt sem tudjuk, hogy milyen kapcsolat létezett

49 1582-ben a nyugat-magyarországi szalónaki úriszék tárgyalt egy hasonló ügyet: miután egy rohonci jobbágy este részegen tért haza a kocsmából, felesége pedig szóvá tette, hogy „ne részögöskönnék, mert annélkül is szegények volnának, annak fölötte adósók is volnának", haragjában egy hasábfával agyonütötte az asszonyt. Úriszék. XVI-XVII. századi perszövegek. Szerk. VARga Endre. Akadémiai, Bp., 1958 (a továbbiakban Úriszék). 68.

50 KvTJk II/13. 171, 174-175; II/14. 16, 23, 151-152, 154, 166; KvSzám18a/VIII. 430; 18b/ VIII. 5-9. 
a házastársak között. A hazatérő férj hirtelen és heves tettéből azonban arra következtethetünk, hogy az alperes hirtelen haragú és lobbanékony természetű, családját szoros felügyelet alatt tartó családfő lehetett, aki a házastársával felmerült nézeteltéréseit nem álláspontjaik közelítésével, hanem fizikai erőfölényének érvényesítésével, felesége fizikai büntetésével orvosolta. Az eset arra is rávilágít, hogy a családi béke és az állam békéjének összefüggései kapcsán a bevezető részben is megfogalmazottakkal összhangban, a közvádlók a házastársi nézeteltérésre nem két személy csupán magánjellegű vitájaként, hanem - amint azt ki is fejtették - az egész városi közösség biztonságát veszélyeztető cselekményként tekintettek, és, mint ilyet, hivatalból üldözendőnek értékeltek.

Nagyon hasonló tényállású ügy került a városi bírák elé negyedszázaddal később, 1656-ban is. Közvádlói minőségükben szintén a városi jogügyigazgatók idézték törvény elé, és kértek halált felesége életének kioltása miatt a Kül-Magyar utcában lakó Csatári Györgyre. Szerintük ugyanis az asszony egy 1655 karácsonya táján szerzett sérülés miatt vesztette életét, melyet a férje által, hirtelen haragjában, a fejéhez vágott tárgy okozott. A vádlott azonban hárítani próbálta a felelôsséget, állítva, hogy ő feleségét ugyan megütötte, de karácsony előtt hat héttel, tehát jóval a direktorok által jelzett időpont előtt. Továbbá azt is hangsúlyozta, hogy az ütés az asszonynak csupán kisebb karcolásokat okozott, és semmiképpen sem vezethetett annak halálához. Fennmaradt tanúvallomások hiányában további részleteket csupán a végítéletból tudunk meg. Például azt, hogy a sérülést követően többen intették az asszonyt, hogy sebe ellátása érdekében forduljon borbélyhoz, de ő elutasította azt. Ennek fényében, s mivel a vádlóknak nem sikerült kétséget kizáróan bizonyítani, hogy valóban a sérülések okozták az áldozat halálát, a bírák úgy döntöttek, hogy, amennyiben a vádlott hat társával megesküszik, hogy nem gyilkos szándék vezette, a sérülést követően pedig ô maga is szorgalmazta az orvosi ellátást, akkor élete megmarad, de fejvesztés terhe alatt el kell hagynia a várost. A felek fellebbeztek, a másodfokon ítélkező esküdt polgárok pedig enyhítettek a büntetésen: a felmentő eskü teljesítése esetén engedélyezték, hogy a vádlott a városban maradjon, de vállalnia kellett, hogy józan életet fog élni, ellenkező esetben a cigányok végleg kiverik a városból.

A források nem mondják meg, hogy mi lehetett a vádlott hirtelen haragjának oka, és a bemutatott eseten kívül más adattal nem rendelkezünk a házastársak közötti viszonyról sem. A fellebbezési ítélet utolsó kikötése azt valószínűsíti azonban, hogy a vádlott ittas állapotban követte el tettét, továbbá, hogy az alkoholfogyasztás vélhetően a vádlott mindennapi életének gyakori velejárója lehetett. Így elképzelhető, hogy a házastársak közötti nézeteltérések a férj ivási szokásaihoz és az abból adódó erőszakosságához köthetők.

Utolsó tárgyalt esetünk egy újabb férjgyilkosság, mely sok hasonlóságot mutat a Bakos Varga Márton elleni 1643-as mérgezési perrel. 1647 júniusában szintén a városi jogügyigazgatók fogták perbe néhai Tóth Illés özvegyét, Biller Margitot, akit 
férjének meggyilkoltatásával vádoltak. ${ }^{51} \mathrm{~A}$ vád szerint, miután az asszonyt férje házasságtöréssel vádolva, a városi tömlöcbe vitette, felkereste őt katona szeretője, Szilágyi György, akitől az asszony férjének meggyilkolását kérhette. Amint ugyanis a katona elhagyta a tömlöcöt, a Széna utcai kisajtó előtt egyenesen a férfira támadt, a földre terítette, ott csákányával agyonverte, majd elmenekült a városból. Férje halálában való részességéért a direktorok zsákba varrva vízbe fojtást vagy felnégyelést kértek az asszonyra. Habár tagadta mind a vádat, mind azt, hogy szerelmi kapcsolatban lett volna a tettessel, az összegyúlt bizonyságok alapján a bíróság fejvesztésre ítélte a nőt. Az év végén Szilágyi is a törvény kezére került, akit az említett gyilkossággal, illetve paráználkodással és gyújtogatással való fenyegetéssel is vádoltak. Ô is tagadta az asszonnyal való kapcsolatát, a gyilkosságról pedig állította, hogy azt az áldozat gyalázkodása - „ő inkább élte feleségét, az captivus, magánál” - miatti hirtelen haragjában követte el. A bírák azonban tettét „sicario modo”, azaz bérgyilkosság módjára, orvul elkövetett szándékos gyilkosságnak minősítették, és fél kezének levágását követően fejvételre ítélték. A vádlott fellebbezett, és egy Kolozs és Doboka vármegyei nemesek által kiállított pecsétes levelet is bemutatott arról, hogy már kiegyezett az áldozat egyik atyafiával. Mivel azonban a bírák szerint az áldozat árváival és nem egy távolabbi rokonnal kellett volna kiegyeznie, elutasították a levelet, és helyben hagyták a halálos ítéletet, csupán a fejvétel előtti kézlevágástól tekintettek el.

Forrásaink nem részletezik, hogy az asszony miért bonyolódott szerelmi kapcsolatba egy katonával. Nem tudjuk meg azt sem, hogy korábban már tervezték-e a gyilkosságot, vagy csupán az asszony lefogatása miatti bosszúvágy, esetleg tényleg a férj szitkozódásai miatti hirtelen düh volt a gyilkosság oka. Jól kiviláglik viszont a városban tartózkodó katonák jelenlétének az egész városi társadalom belső rendjét bomlasztó hatása. Az általában idegenből származó, szabadabb, de mégis keményebb életmódhoz szokott, a helyi közösségek társadalmi együttélési normáit gyakran figyelmen kívül hagyó, fegyverforgató férfiak ugyanis könnyen tiltott szerelmi kapcsolatba keveredtek a helyi közösség hajadon vagy férjes nőtagjaival, a felszarvazott férjek ellenlépései pedig gyakran torkollhattak emberéletet követelő erőszakos cselekedetekbe.

Végül megemlítünk még két olyan esetet, ahol gyilkosságra ugyan nem került sor, nem is amiatt folyt a per, de szóba került annak is a lehetősége. 1614-ben a városi jogügyigazgatók bíróság elé állították Daróci Jánosné Károlyi Katát sorozatos házasságtörésért. ${ }^{52}$ Több tanú szerint, az asszonynak viszonya volt Báthory Gábor fejedelem házuknál elszállásolt étekfogójával, akit arra biztatott, hogy férjét „veszesse el”. A férfi azonban visszautasította a tettet, „mivelhogy egy hütön vagyon vélem”. Egy má-

51 KvTJk II/17. 198, 201, 208; KvSzám 25a/I. 753-754.

52 KvTJkII/11.176-178, 192-207,208; Magyar Nemzeti Levéltár Országos Levéltára, R 374 - Kolozsvár városra vonatkozó iratok, II. sorozat, II. kötet, IV. csomag, 11-12. 
sik szeretőjét is arra biztatta, hogy végezzen férjével, majd pedig szökjenek együtt Moldvába. A férj végül életben maradt, az asszony fejedelmi kegyelemmel megmenekült a büntetéstôl, az eset pedig újabb példa arra, hogy egyes feleségek szeretőjük segítségével próbáltak megszabadulni nem kívánt házasságukból. ${ }^{53}$ 1630-ban Kádár Jánosné Anna ellen pereltek a jogügyigazgatók, házasságtöréssel, kerítéssel és féktelen életmóddal vádolva őt. A kocsmában részegeskedő, fiatal legényekkel paráználkodó és kerítéssel is foglalkozó asszony rossz házasságban élt, férje bántalmazta őt. Talán e káros kapcsolatának próbált véget vetni akkor, amikor - az egyik tanú szerint férjét is megpróbálta megölni, de fia tolvajkiáltása meghiúsította tervét. ${ }^{54}$

\section{PERESFELEK, BÜNTETÉSEK, OKOK, KÖRÜLMÉNYEK}

A vizsgált időszakból hét olyan esetet rögzíthettünk, ahol házastársak támadtak egymás életére, kettőben pedig csak mellékesen merült fel a házastársi gyilkosságnak a szándéka. Minthogy forrásaink hiányosak, az időszak pereinek száma biztosan nagyobb, így a következőkben csupán óvatos észrevételeket tehetünk. A fennmaradt adataink alapján a városi törvényszék elé került esetek 6-7\%-a indult emberélet elleni büncselekmények miatt, ezek kb. 15\%-a volt családon belüli emberölés, és ezen belül is az eseteknek csupán a negyedét képezték a házastársi emberölések vagy gyilkosságok. Az arány a kora újkori Európa más területeihez hasonló, és, akárcsak máshol, itt sem nagy számuk, hanem közösségi visszhangjuk miatt vetült rájuk kiemelt figyelem. ${ }^{55} \mathrm{~A}$ perek alacsony száma alapján azt mondhatjuk tehát, hogy a kora újkori Kolozsváron a házastársi nézeteltérések nem fajultak túl gyakran emberéletet követelő összetűzésekig. Azonban mivel nem ismerjük az arányt a ténylegesen megtörtént, illetve a bíróság elé került esetek között, e megállapításunk is megkívánja az óvatosságot. ${ }^{56}$

53 Számos részletében a fentihez hasonló ügy került 1639-ben a székelyvásárhelyi bírák elé. Szántai Csizmadia János perbe fogta feleségét, aki a fennmaradt vallomások szerint több ifjúval, köztük férje céhlegényeivel tartott fenn szerelmi kapcsolatot. Kettőt férje meggyilkolására is rá próbált venni. Egyiknek jó adag pénzt és ruhanemút ígért, ha megöli férjét, majd pedig Nagybányára szöknek, és ott összeházasodnak. A legény nem hajlott a gyilkosságra, de szerzett higanyt az asszonynak, amelyet ô hol levesbe, hol káposztába, hol italba keverve adott be férjének, de eredménytelenül. Egy másik legénnyel is próbálkozott, aki titokban rá is fogta fegyverét a gyanútlan férjre, de végül ő is elállt a tettől. Asszonyok és férfiak tüköre. Tanúvallomások a XVII. századból. Szerk. VígH Károly. Pallas-Akadémia, Csíkszereda, 1999. 285-291.

54 KvTJk II/13. 34-36, 38-39, 124, 127, 130, 131; KvSzám 18a/VIII. 425-428.

55 McMahon: i.m. 192.

56 Még akkor is, ha számba vesszük azt a szakirodalmi megállapítást, hogy a családi erőszak tanulmányozására az emberölési ügyek éppen azért a legalkalmasabbak, mert egy gyilkos- 
A bemutatott hét esetből négyszer a városi jogügyigazgatók képviselték a vádat, Illés János esetében szintén hatósági személy, a papfalvi officiális volt a felperes, Igyártó György saját maga indított perben tisztázta ártatlanságát, Géci Katalint pedig férje vádolta. Öt alkalommal tehát hivatalból indult per a vádlottak ellen. E tény erősíti a városi jogügyigazgatók 16. század végi tevékenységének elemzése kapcsán megfogalmazott azon véleményt, hogy az intézmény megjelenése meghatározó intézkedésnek bizonyult - egyéb bűncselekmények mellett - a családi erőszak leleplezése, büntetése és visszaszorítása szempontjából is, ${ }^{57} \mathrm{~s}$ a közbiztonság javítása révén, végső soron társadalmi és államérdeknek számított a kora újkori Európában. ${ }^{58} \mathrm{~A} 16$. század végi emberölési ügyek vizsgálata megmutatta, hogy a rablógyilkosságok mellett, az összes családon belüli emberölési ügyben (csecsemőgyilkosságok, szülő általi gyermekölések) a direktorok kezdeményezték a bírósági eljárást. Az intézmény megjelenése előtt ilyen pereket nem tárgyalt a városi bíróság, magánvádló hiányában e tettek elkövetói tehát jó eséllyel elkerülték a törvényt. A most bemutatott esetek is azt mutatják, hogy a házastársuk életét kioltó személyek is jórészt a közvádlók fellépése következtében kényszerültek szembenézni az igazságszolgáltatással. Szebeni Mihály mészárosmester esete jó példa az elmondottakra. A direktorok bíróság elé idézték őt, de ő kifogásolta a lépés jogosságát, mert szerinte csak az asszony élő atyjafiai élhettek volna a perindítás jogával. A bírák kikötötték, hogy csak úgy adnak helyt a kifogásának, ha az áldozat hozzátartozói a következő két törvénynap valamelyike alkalmával élnek keresetindítási jogukkal, ellenkező esetben „procedálhatnak director uraim ez causájokban”, tehát folytatódhat az általuk megkezdett eljárás. Magánvádlók nem jelentkeztek, így a direktorok keresete maradt érvényben, és az ő indítványukra ítélték első fokon fejvesztésre a vádlottat.

A vádlottak között volt papfalvi jobbágy, katona, a városban szolgáló idegen ifjú, de jó részük a városban házzal rendelkező polgárok sorából került ki. Igyártó György a város elismert prókátora volt, Géci Katalin egy városi centumvir lánya, Szebeni Mihály pedig a Szappan utcai házában lakó mészáros. Köztük volt még a Kül-Magyar utcából Csatári György, vagy a vélhetően sütőházi dagasztónő, Biller Margit. A vádlottak társadalmi helyét vizsgálva azt mondhatjuk tehát, hogy a házastárs életének

ságot jóval nehezebb volt eltitkolni, mint a családi erőszak más formáit, így ezen esetek nagyobb arányban kerültek a törvény elé. Sharpe: Domestic Homicide 32-33. Viszont például a kora újkori Bologna esete, legalábbis a mérgezések kapcsán, arra figyelmeztet, hogy annak ellenére, hogy a városi feltárt esetek között nagyon alacsony a mérgezés miatt elítélt személyek száma, valójában sok ügy vagy elakadt még a per feljelentési fázisában, vagy pedig nem is került a bíróság elé, mert nem sikerült azonosítani a mérgezés tényét. PASTORE: i. m. 234-235.

57 Pakó László: A városi közügyigazgatók (direktorok) Kolozsvár 16. század végi birósági gyakorlatában. Erdélyi Múzeum LXXIV(2012).3. sz. 99-101.

58 Nolde: i.m. 146. 
kioltásával járó nézeteltérések a városi elitet képező előkelő polgárok, a kézmúves foglalkozású városiak, a szerény anyagi helyzetû szolgálók vagy a város falvaiban élő jobbágyok családjaiban egyaránt előfordulhattak.

A tettesek nemenként való eloszlása szempontjából az általános vélekedések szerint a férfiak általában gyakrabban törtek házastársuk életére, mint az asszonyok. ${ }^{59}$ Kolozsvári eseteinkben azonban a hét ügyből háromban vagy nők voltak a tettesek, vagy ők kezdeményezték a gyilkosságot, és vették rá az elkövetőt a tettre. Ha azon két esetet is figyelembe vesszük, ahol csak felmerült a férjgyilkosság szándéka, akkor a mérleg nyelve a nők felé billen. A korábbi kijelentés tehát Kolozsvár esetében egyelőre árnyaltabban értelmezendő. Kizárólag a mérgezéses eseteket vizsgálva is azt látjuk, hogy gyakrabban vádoltak feleségeket, mint férfiakat, házastársuk életének kioltásával. A mérgezés tehát - akárcsak a kora újkori délnémet kisvárosok esetében, és ellentétben sok más angliai vagy itáliai, korábban már említett térséggel ${ }^{60}$ - a kora újkori Kolozsvár esetében is inkább női bűncselekménynek tekinthető, de a perek kis száma miatt, továbbá mivel Géci Katalin pere esetében felmerül a kétely, hogy férje éppen e sztereotípiára rájátszva próbálta feleségét hamis mérgezési váddal eltenni útjából, ${ }^{61}$ egyelőre elhamarkodott lenne szilárd következtetéseket levonni.

A bemutatott esetek közül két véghezvitt és egy tervezett gyilkosság kapcsán merült fel tettestársak közremúködése. Minden esetben a feleség vonta be szeretőjét, szeretőit a tettbe, így Kolozsvár is azt az általános megfigyelést erősíti, hogy a férjük életére támadó asszonyok jóval többen cselekedtek tettestársakkal. És ezek egy része itt is a háztartásban szolgáló idegenek közül került ki. ${ }^{62}$ Minden férjgyilkos feleség szerelmi kapcsolatot tartott fenn idegennel, így Kolozsvár esetében is megállapítható az a máshol is tapasztalható jelenség, miszerint számos tett a feleségek házasságon

59 Dwyer Amussen: i. m. 76; Dolan: Dangerous Familiars 89; Spierenburg: i. m. 136. Az angliai Essex 1560-1709 közötti házastársi gyilkossági eseteiben az áldozatok kétharmada a feleségek közül került ki. Sharpe: Domestic Homicide 37. Essex, Hertfordshire és Sussex 1559-1625 közötti eseteit vizsgálva az arány még inkább a feleségek irányába mozdult el, ugyanis az esetek háromnegyedében voltak ők az áldozatok. J. S. CockвuRn: The Nature and Incidence of Crime in England 1559-1625: A Preliminary Survey = Crime in England, 1550-1800. Ed. J. S. CосквURn. Routledge, London and New York, 2016. 57; Dolan: Home-Rebels 7-8. A 17-18. századi orosz házastársgyilkossági esetek háromnegyedében a feleség és csupán negyedében volt a férj az áldozat. Marianna Muravyeva: "Till Death Us Do Part". Spousal Homicide in Early Modern Russia. The History of Family 18(2013). 3. sz. 311-312.

60 Spierenburg: i. m. 130-131. Lásd még a 43. és a 44. jegyzeteket.

61 Pieter Spierenburg is több olyan angliai esetet említ, amikor feleségmérgezéssel vádolt férfiak e sztereotípiát saját hasznukra fordítva próbálták tetteiket szolgálóikra vagy más asszonyokra hárítani, ezáltal pedig szabadulni a vádak alól. Spierenburg: i. m. 130.

62 Uo. 138. 
kívüli kapcsolatainak lett a folyománya. ${ }^{63}$ Igyártó György esete azonban, aki feleségét tette el láb alól szeretője miatt, figyelmeztet, hogy léteztek kivételek is.

A kirótt büntetések tekintetében számos példa mutatja, hogy aki kioltotta házastársa életét, gyakran saját életével fizetett tettéért. A büntetés mértéke azonban a tett körülményeitől függően változott. 1569 decemberében Zele Anna azért vesztette el életét, Kraszna vármegyei birtokrészeit és szőlőhegyét, mert férjét megöletve, a hütlenség és felségsértés bűnébe esett. ${ }^{64} \mathrm{~A}$ 16. század végi Désen egy asszony megölette férjét egy legénnyel, mindkettőjüknek fejét vették. ${ }^{65} \mathrm{~A}$ fejvesztés büntetését kérte 1668-ban a Torda vármegyei törvényszék előtt a megye hivatalból perelő alispánja is egy, feleségét saját kezével megölő fogolyra ${ }^{66}$ Fejvételre ítélte 1582-ben a szalónaki uradalom úriszéke azt az ittasan a kocsmából hazatérő jobbágyot is, aki felesége szemrehányásai miatt, haragjában egy hasábfával halálosan megütötte oot. ${ }^{67} 1588$-ban a németújvári uradalom úriszéke előtt egy férfit apósa vádolt feleségének megölésével. A vádló szerint a holttesten erős verés nyomai voltak, és a férj már a házasság hatóság által kikényszerített megkötésekor hangoztatta, hogy „elveszem, de sokáig bizton nem él”. A bíróság a bizonyítékok alapján nem látta bizonyítottnak a gyilkosságot, így a vádlottat fejvesztésre ítélte, ha igaza mellett negyvenedmagával esküt nem tesz. ${ }^{68}$

Ha a szándék kétséget kizáróan bebizonyosodott, kemény volt a megtorlás. 1580ban Bártfán egy fiatalasszonyt és két unokatestvérét ítéltek el, mert vérfertőzést követtek el, majd kioltották a férj életét. Az asszonyt élve eltemették, szívét pedig a gödörben egy karóval átdöfték, a fiúkat viszont - habár a jegyző szerint jóval keményebb büntetést érdemeltek volna - csak lefejezték, mert szüleik és mások is közbenjártak érdekükben. ${ }^{69}$ 1683-ban a munkácsi úriszék a feleségét éjjel álmában megölő jobbágy esetében határozott úgy, hogy „hóhér kezébe adatván elsőben is jobb keze

63 Uo. 139

64 Az erdélyi fejedelmek királyi könyvei. I. János Zsigmond királyi könyve 1569-1570. Mutatók, jegyz., reg. FejÉr Tamás-RÁcz Etelka-SzÁsz Anikó. EME, Kvár, 2003 (Erdélyi Történelmi Adatok VII. 1). 208. reg.

65 A tett további részleteit nem ismerjük. SzÁsz Anikó: Dés városvezetése 1541-1600 között. Erdélyi Múzeum LXXX(2018). 1. sz. 69-70.

66 A szék arra kérte az alispánt, hogy a következő széknapig derítsen fényt a tett körülményeire, különösen arra, hogy a vádlott szántszándékkal vagy anélkül követte el tettét. Torda vármegye jegyzőkönyvei. II. 1659-1707. Bev., jegyz. DÁné Veronka. EME, Kvár, 2014 (Erdélyi Történelmi Adatok IX. 2). 66.

67 Úriszék 68.

68 Uo. 259-260; PÉTER Katalin: Házasság a régi Magyarországon, 16-17. század. L'Harmattan, Bp., 2008. 63.

69 Blanka SzegGryová: Eröszak és konfliktuskezelés a polgárok mindennapi életében a 16. században = Bártfától Pozsonyig. Városok a 13-17. században. Szerk. CsuKovits Enikő-LengYeL Tünde. MTA TTI, Bp., 2005. 233-234. 
vágattassék el, és annak utána négy felé vágatván, teste ugyan négy akasztófára akasztassék". ${ }^{70}$ A 17. század végi Pest ítélkezői sem kímélték a férjgyilkosokat. A német birodalmi törvények, különösen a szigorú büntetéseirôl ismert Constitutio Criminalis Carolina hatására 1689-ben egy asszonyt és az általa férje meggyilkolására 100 forintért felbérelt férfit karddal történő kivégzésre, kerékre fonásra és testüknek a vesztôhelyen való elhantolására ítélte. ${ }^{71} 1693$-ban egy másik asszonyt ítéltek jobb kezének, majd fejének levágására, és a levágott testrészek kerékre túzésére. ${ }^{72}$ 1747-ben a debreceni bíróság előtt egy polgárasszony és szeretője ismerték be, hogy már jó ideje tervezték az asszony férjének meggyilkolását. Méreggel is próbálkoztak, sikertelenül, végül az asszony biztatására és az általa szerzett csákánnyal a legény az erdőn, éjjel, álmában leütötte a férfit, egy szíjjal megfojtotta, majd a holttestet a ló után kötve, balesetet próbáltak színlelni. Tettükre fény derült, és a bírák - minthogy „férjével egy test lévén, mint maga testét, úgy kellett volna minden veszedelemtől oltalmazni, nem hogy [...] megölésére mást izgatni és azt tanáccsal tartani” - elrendelték, hogy karját kétszer fogdossák meg tüzes fogókkal, vegyék fejét, majd testét húzzák karóba, és állítsák közszemlére. A tettes szeretőjét is jobb kezének levágására, fejvételre és testének kerékre tevésére ítélték. ${ }^{73}$

Kemény büntetésre számíthattak a férjeiket megmérgező asszonyok is. 1608 májusában egy gyulafehérvári asszony ellen perelt a mezőváros bírája, akit egy tordai mester megmérgezésével vádolt, illetve azzal, hogy egy másik, szintén városi asszonynak ő adott higanyt, amellyel az a saját férjével végzett. A vádlott tagadott, a bizonyítékok pedig nem győzték meg minden kétséget kizáróan az ítélkezőket, így tűz általi halálra ítélték, ha saját igazára nem tenne esküt hetedmagával. ${ }^{74} 1743$-ban Sopronban fejvételre ítéltek egy asszonyt, a szeretőjét és egy méregkeverő asszonyt, majd tetemeiket kerékbe törve közszemlén hagyták, mert együtt végeztek az asszony férjével..$^{75}$ 1744-ben egy szeretőt tartó debreceni asszony fölött mondtak ítéletet, aki a szolgálójával a patikából rühirtás címén vásároltatott és borba csempészett szerrel mérgezte meg a férjét. Miután a halotti szemle és a boncolás során a városi orvos és borbélyok megállapították a mérgezés tényét, az elfogott asszony pedig a kínvallatás

70 Ecкhart Ferenc: A földesúri büntetóbiráskodás a XVI-XVII. században. Akadémiai, Bp., 1954. 116.

71 Az asszony - a forrás szerint orvul - kegyelmet szerzett magának, de a tettest kivégezték. Bónis György: Buda és Pest birósági gyakorlata a török kiúzése után, 1686-1708. Akadémiai, Bp., 1962. 138.

72 Uo. 139.

73 M. Antalóczy Ildikó: Bünözés és büntetés Debrecenben a XVIII. század közepén. Csokonai, Debrecen, 2001.123.

74 Gyulafehérvár város jegyzőkönyvei. Bev., jegyz., közzéteszi Kovács András. EME, Kvár, 1998 (Erdélyi Történelmi Adatok VI. 2). 233-234, 236.

75 Win KLER Elemér: Bünök és büntetések a régi Sopronban. Sopron, 1924. 48. 
során beismerte tettét, a bírák karján tüzes fogókkal való kétszeri megégetésre, fejvételre és karóba húzásra ítélték. ${ }^{76}$

Tárgyalt ügyeinkben, papfalvi Illés János és Bakos Varga Márton esetében, nem maradt fenn az ítélet. Igyártó György ügyének sem maradt fenn az ítélete, de későbbi tevékenysége alapján feltételezzük, hogy felmentette magát a feleséggyilkossági vádak alól. Elitélték viszont Biller Margitot és szeretőjét, Szilágyi Gyurkó katonát Tóth Illés meggyilkolása miatt. A direktorok szigorú büntetéseket, az asszonyra zsákba varrva vízbedobást vagy testének felnégyelését, a katonára pedig még súlyosabb, kínzást követő négyelést vagy karóba húzást kértek. A bírák azonban mindkettőjüket az enyhébb büntetésnek számító fejvesztésre ítélték, a férfi esetében fél kezének levágását is elrendelve, de ezt a fellebbezés során eltörölték. Az ítéletek nem részletezik az enyhébb megítélés okát, de vallomásában a tettes kiemelte, hogy az áldozat a sebesítést megelőzően gyalázkodott, ami felharagította őt, továbbá a tény, hogy a tettes lépéseket tett az áldozat rokonaival való kiegyezésre, úgy gondoljuk, befolyásolhatta a döntést. A bírák első fokon bünösnek találták, és a direktorok által is kért fejvételre ítélték Szebeni Mihály mészárost is. Ítéletüket alaposan megindokolták: a tanúk is állították, és a tettes is beismerte, hogy valóban fejbe ütötte csákányával feleségét; halála előtt az asszony a férje bűnösségére vallott; a sebet megvizsgáló borbélyok szerint is a sérülés okozta a halált; a vádlott állításai ellenére, az aszszony a bántalmazás után többé nem tudott talpra állni; a vádlott nem tudta bizonyítani gyilkos szándékának hiányát. A fenti esetek azt mutatják tehát, hogy a kétséget kizáróan bünösnek ítélt vádlottak életükkel fizettek tettükért, de a büntetés súlyosságának megítélésében számos körülményt mérlegelve hoztak döntést.

Ha viszont a bizonyítékok kétséget kizáróan nem támasztották alá a vádlottak búnösségét, elmaradt a halálbüntetés. Géci Katalint a bírák - habár erős volt a gyanú, hogy „urához való kötelessége ellen cselekedett” - perdöntő bizonyíték hiányában negyedmagával felmentő esküre ítélték. S annak ellenére, hogy a másodfokon ítélkező esküdt polgárokban a gyanú tovább fokozódott az asszony búnösségével kapcsolatosan, perdöntô bizonyíték hiányában fenntartották a bírák ítéletét, csupán az eskütársak számát emelték hatra. A feleségét haragjában bántalmazó Csatári György esete a legbeszédesebb ilyen tekintetben. Halála előtt az asszony a férje által okozott sérülését nevezte meg halála okául, de a bírák ezt nem tekintették perdöntő bizonyítéknak. Hangsúlyozták, hogy sérülését követően az asszony nem fordult borbélyhoz sebének ellátása érdekében, így túlélési esélyeit saját maga csökkentette. Továbbá az áldozat e mulasztása miatt, ők sem támaszkodhattak szakértői véleményre a halál tényleges okának a megállapításakor. A tettes mellett szólt továbbá az is, hogy ő is borbély felkeresésére biztatta sérült feleségét. Így, habár az ügy sok részlete hasonlí-

76 Az ítélet indoklásában kifejtették, hogy „sokkal nagyobb gonoszság légyen az embernek maga házastársát megölni, mintsem más idegent”. M. AnTALóczy: i. m. 124. 
tott Szebeni Mihály esetéhez, a bírák felmentették a vádlottat, ha hetedmagával bizonyítja, hogy nem gyilkos szándék vezette tettére. A férfi letette az esküt, s miután józan életet is fogadott, szabadult a vádak alól. A vádlott tehát nem azért kapott esélyt az esküre, mert a bírák ártatlannak ítélték, hanem mert bünössége nem bizonyosodott be kétséget kizáróan.

Két esetben fejvétel általi halálra ítélték a vádlottakat, két esetben a vádlottak felmentő esküvel menekültek a vádak alól, egy esetben csak a későbbi történésekből gondoljuk, hogy a vádlottat felmentették, két esetben pedig nem ismerjük a perek végkifejletét. A kevés esetből egyelőre nehéz arról nyilatkozni, hogy a büntetések kiosztásánál nemi megkülönböztetésre került-e sor. Biller Margit és katona szeretője ügyében észlelni csupán némi különbséget a felperes direktorok által kért büntetésekben: a felbujtó feleségre zsákba varrva vízbedobást - mely leggyakrabban a boszorkányoknak és a (visszaeső) paráznáknak volt a büntetése - vagy felnégyelést kértek, míg a tettet végrehajtó szeretőre kínzással súlyosbított felnégyelést vagy karóba húzást. A bírák azonban végül mindkettőjüket fejvételre ítélték. ${ }^{77}$ Meglévő kevés adatunk alapján a kirótt büntetések neme és a büntetettek társadalmi rangja közötti esetleges összefüggésekről sem szólhatunk. ${ }^{78}$

A fenti adatok viszont alátámasztják azt a, például a reneszánsz kori itáliai városok mérgezési pereinek esetében is hangsúlyozott megállapítást, miszerint az ítélkezők a bizonyítás során, felismerve az orvosi ismeretek büntetôperekbe való bevonásának a szükségét és előnyeit, egyre gyakrabban vették igénybe az orvos szakértők véleményét. ${ }^{79}$

77 Az orosz kora újkori példák azt mutatják, hogy annak ellenére, hogy a feleségek a házastársi gyilkosságok csupán negyedét követték el, tetteik sokkal nagyobb figyelmet kaptak, és mind a törvények, mind pedig a gyakorlat során jóval szigorúbban büntették őket, mint a feleséggyilkos férjeket. Halálbüntetést például a férfi elkövetők 1,3\%-a kapott, míg a női elkövetők 21,4\%-a; a gyilkos férjeket akasztásra vagy fejvesztésre ítélték, a gyilkos feleségeket viszont élve elhantolták; a férfiak esetében az előírt halálbüntetéseket csak ritkán hajtották végre, a nők esetében jóval gyakrabban; kolostori fogság esetén a feleségek jóval hosszabb büntetésre számíthattak; a férjek tetteinek harmadát, a feleségek tetteinek viszont csupán 4\%-át kezelték nem szándékos gyilkosságként, amely kisebb büntetést vont maga után. Shields Kollmann: The Extremes of Patriarchy 134-135; Uő: Crime and Punishment in Early Modern Russia. Cambridge University Press, Cambridge, 2012. 284-287; Muravyeva: i. m. 312-313, 322-323. Az angol jogrend is a gyilkos feleségeket mint az uraik és feljebbvalóik ellen lázadó alattvalókat kisebb felségárulással, tehát súlyosabb váddal illette, és megégetéssel büntette, míg a gyilkos férjeket, más gyilkosokhoz hasonlóan, akasztást követő felnégyeléssel. Dolan: Home-Rebels 3-4; Caswell: i. m. 108; Hall-Malcolm: i. m. 281.

78 Olyan elkülönülést, mint például Bologna kora újkori mérgezési ügyeinek esetében, ahol a mérgezést elkövető elit tagjainak lefejezés, míg az alacsonyabb társadalmi rétegeknek akasztás járt, nem tapasztaltunk. PAstore: i. m. 236.

79 Uo. 228. 
Kevés az olyan tárgyalt eset, ahol világosan elkülöníthetők a tettek elkövetésének indítékai. Papfalvi Illés János ügyében egyértelmú, hogy a házasok rossz kapcsolatban éltek, hogy a férj erőszakos természete, melyet a gyakori alkoholfogyasztás is alakított, volt a tragédia oka. Rossz kapcsolatban élt Igyártó György és első felesége is. Az asszony halálához a férj azon igyekezete vezetett, hogy új szeretőjének helyet csináljon családjában. Szebeni Mihály és Csatári György vélhetően hirtelen felindulásból cselekedtek. Szebeni esetében talán a feleségével együtt talált inas elleni féltékenység, Csatári esetében pedig az elfogyasztott alkohol válthatták ki azt a hirtelen reakciót, amely az áldozatok halálához vezetett. Azt azonban nem tudjuk, hogy az ilyen ügyek mindennaposak voltak-e a két család életében, vagy csupán egy-egy szerencsétlen kimenetelű esettel állunk szemben.

Keveset tudunk a férjeik életére törő vagy ellene szövetkező asszonyok házaséletérôl is. Géci Katalin - ha valóban próbálkozott férje megmérgezésével, és nem csak a férj színjátéka volt az egész -, elképzelhető, hogy egy számára romboló hatású házasságból próbált menekülni. Szénégető Lơrincné talán egy új élet reményében szökött meg, és házasodott össze az idegenből származó szolgával, míg Biller Margitot és katona kedvesét vélhetően a bosszú vitte a gyilkosságra a kalandjuk útjában álló férj ellen. Daróci János, Károlyi Kata férje, kezdeti ellenkezése ellenére, beletörődéssel vette tudomásul felesége szerelmi viszonyait, az asszony azonban újabb és újabb kapcsolatokba bonyolódott, egyszerre több férfit is hitegetve a házassággal, ha végeznek férjével. Vélhetően miatta nem állhatott helyre kettejük jó családi viszonya. Kádár Jánosné rossz házasságban élt, férje gyakran verte és szidalmazta őt, de vélhetően az asszony is felelős volt kapcsolatuk megromlásáért. Többen számoltak be katonákkal töltött kocsmai italozásairól, lopásairól, paráznaságairól és egyéb tetteirooll.

Minthogy a szeretőikkel szövetkező asszonyok általában férjeiknél bizonytalanabb anyagi helyzetben lévő férfiakat választottak új partnerül, nem gondoljuk, hogy az anyagi haszonszerzés vágya motiválta választásaikat. E tekintetben a házassági ígéretért cserében kedvesétől értékes gyürúket elfogadó, majd a kapcsolat megszűnése után azokat vissza nem szolgáltató Daróci Jánosné jelenthet kivételt. Ulinka Rublack szerint a férjgyilkos asszonyok motivációi hátterében általában nem a kegyetlenség, hanem a szabad önrendelkezés iránti vágy állott. ${ }^{80}$ Pereink esetében ez több asszonynál feltételezhető, azonban a források ilyen jellegú adatainak hiánya biztos állításokra nem jogosít fel. Forrásaink arról sem szólnak, hogy a házastársak szexuális életéhez kapcsolódó gondok álltak-e a gyilkosságok hátterében.

80 Rublack: i.m. 229. 
Az viszont bizonyos, hogy a házastársi hűség semmibevétele, ${ }^{81}$ a felek rossz, erőszakos természete, az alkoholfogyasztás, ${ }^{82}$ a katonák városi jelenléte, illetve a családokkal egy háztartásban élő szolgák, szolgálók jelenléte jelentősen befolyásolták a történteket. A férfiak több tettét hirtelen harag váltotta ki, vélhetően feleségüknek az általuk ,jogosnak” itélt büntetése sikerült túl erősre. Az asszonyok tetteire nem a hirtelen felindulás a jellemző, a férjeiknél kisebb fizikai erejük nem is tette ezt lehetővé. Ők előre megtervezték, és gyakran mással, leggyakrabban szeretőikkel szövetkezve hajtották végre cselekedeteiket. Mivel számos körülményt azonban nem fednek fel forrásaink, nehéz további megállapításokat tenni. De amint más kutatók is hangsúlyozzák, valójában még a körülmények jobb ismeretében is szinte lehetetlen a házasságok összeomlásának egyetlen pontos okát azonosítani, azok eredőjét ugyanis általában több körülmény halmozódásában kell keresnünk. ${ }^{83}$

A büncselekmények végrehajtásához használt eszközöket vizsgálva, mérget három esetben használtak, két alkalommal biztosan a higanyt, mely népszerűnek számított a korban. ${ }^{84}$ Tekintve, hogy orvoslásra is használták, egyszerúbben és kisebb feltúnéssel lehetett hozzájutni, ugyanakkor a tettet is könnyebb volt gyógyításnak álcázni. Egy esetben a férj puszta kézzel verte halálra feleségét, két esetben csákánnyal került sor a halálos sebesítésre, Csatári György esetében pedig nem ismerjük a tett elkövetésének eszközét. Ha a méreg használata során nyilvánvaló a tettes előzetesen eltervezett, gyilkos szándéka, a többi esetben azonban a tettesek az éppen kezük ügyébe kerülő tárggyal gyilkoltak. S mivel a fegyverhordás elterjedt szokásnak számított a korban, nem meglepő, hogy gyakran éppen a fegyver vált a gyilkosság eszközévé.

Bemutatott pereink, alacsony számuknak is köszönhetően, nem adnak átfogó képet a házastársi erőszak korabeli mértékéről, gyakoriságáról és formáiról. A halállal végződő esetek mellett a házastársaikat testi épségükben, de nem halálosan megsértő vádlottak ellen indult eljárások tartalmazhatnának további ilyen részleteket, de a törvénykezési jegyzőkönyvekben ilyen perek nem szerepelnek. Ezek az ügyek ugyanis

81 A pápának címzett magyarországi késő középkori bűnbocsánati kérelmek között számos olyat találunk, melyben hűtlen feleségük „ördögi ösztönzésre”, hirtelen haragból vagy mély fájdalomból elkövetett megölése miatt kértek férfiak feloldozást. ERDÉLYi Gabriella: A Sacra Poenitentiaria Apostolica bivatala és magyar kérvényei a 15-16. században. (I. közlemény). Levéltári Közlemények 74(2003). 1-2. sz. 47; Uő: Nók a bún hálójában. Becsület, szexualitás és a társadalmi nemek közötti viszonyok a késő középkori Magyarországon. Publicationes Universitatis Miskolciensis. Sectio Philosophica XXI(2017). 2. sz. 132.

82 A kora újkori holland városok esetében a kutatás kimutatta, hogy az alkoholfogyasztás szorosan összekapcsolódott a családi erőszakkal, ugyanis az ilyen bűnökben elítéltek negyede ittas volt tette elkövetésének idején. Heijden: Women and Crime 154.

83 Sharpe: Domestic Homicide 42-44.

84 Az említett 1608-as gyulafehérvári és az 1639-es székelyvásárhelyi esetekben is a vádlottak higannyal próbálták házastársuk életét kioltani. Lásd az 53. és a 74. jegyzeteket. 
- akárcsak máshol ${ }^{85}$ - ritkán kerültek a világi bíróság elé, vélhetően az áldozatoknak a szégyentől vagy jogi lépéseik gazdasági, társadalmi, esetleg más következményeitől való félelme okán. ${ }^{86} \mathrm{Az}$ egyházi bíróságok jegyzőkönyvei jóval több adatot tartalmaznak a házastársak egymás ellen elkövetett erőszakos cselekedeteiről, de így is csak azokról az esetekrôl szerzünk tudomást, melyek során az asszony beavatta az egyházi hatóságot házassági gondjaiba. Ezen esetek száma viszont messze elmaradt a valóban megtörtént, de hatóságnál nem jelentett esetek számától. ${ }^{87}$

Ha a családban, ezen belül is a házastárs élete ellen elkövetett emberölések számát a más típusú élet elleni büncselekmények számához hasonlítjuk, kiviláglik, hogy nem ezek voltak a korszak emberöléseinek jellegzetes formái. Az emberéletet kioltó cselekmények legtöbbjére nem a családi környezetben, hanem azon kívül került sor. A házastárs élete ellen elkövetett büncselekmények tehát legtöbb esetben olyan emberek életének voltak szerencsétlen mozzanatai, akiknek az agresszivitás, az alkohol, a hủtlenség, a szóbeli és fizikai erőszak határolta be mindennapjait.

\section{CRIME WITHIN THE FAMILY. SPOUSAL HOMICIDE IN EARLY MODERN CLUJ}

\section{Keywords: early modern time, domestic crime, spousal murder/manslaughter, poisoning, criminal prosecution}

Based on the judicial protocols and on the account books of the town between 1570 and 1660 , the study deals with the spousal homicide cases of early modern Cluj. Seven such cases were preserved, and two others that implicated accusations of such kind. The number of the cases is relatively small, thus our conclusions more fragile. In three of the cases poison was the

85 Hall-Malcolm: i.m. 277. Németalföldi városok (Delft, Rotterdam) példái azt mutatják, hogy a családi erőszakot elszenvedett személyek az agresszió megfékezése érdekében általában a kevésbé radikális megoldásokat részesítették előnyben. Ha a törvénytől vártak megoldást, akkor ritkán indítottak rendes büntetôpert, mert a férj esetleges hosszú bebörtönzése vagy városból kiủzése a család jövedelmeit csökkentette, ez pedig az áldozatoknak is kárára volt. Inkább sommás, gyorsított eljárású, kisebb anyagi büntetést vagy rövidebb fogságot kirovó perek során próbálták figyelmeztetni az elkövetőket tettük súlyáról. Máskor a városi szomszédságokhoz vagy az egyházi intézményekhez fordultak segítségért. HeijDen: Women and Crime 81, 155-159.

86 A vizsgált időszakban csak néhány olyan pert találtunk, és ezek sem házastárs bántalmazása miatt indultak, amelyekben a házastársak közötti összetűzésekről is szót ejtettek a tanúk. KvTJk II/9. 93-96, 99-102; II/11. 100-104, 113-114, 124, 136-137; II/13. 169.

87 A kutatás a kora újkori Európában legfeljebb 5\%-ra becsüli azon városi nők arányát, akik házassági gondjaik megoldása érdekében megkeresték az egyházi vagy világi hatóságokat, és ezeknek is csak a töredéke kérte a férjeiktől való elválasztást. Legtöbbjük az eljárástól csupán férjeik túlzott fenyítő hatalmának korlátozását és saját, családon belüli érdekérvényesítő képességüknek javítását remélte. Géra: i. m. 136-137. 
lethal weapon, in two of these cases the wife, and in one case the husband being the perpetrator or the impeller. In other cases, the crimes occurred in direct and open confrontation, the majority of the culprits were men. In seven cases the criminal procedures started through public initiation, the charges being represented mainly by the two public prosecutors (directores causarum) of the town. As of the social status of the perpetrators, our examples show that people of all social categories, from honourable citizens to the serfs of the town were implicated. Although other examples have shown that men killed their wives more frequently, the distribution of the offenders on sexes in our case is more balanced. In three of the cases accomplices intervened, all of them were men in an intimate relation with the criminal wives. Those found guilty by the judges were usually decapitated, but if the guilt was not sustained by solid proof, the defendants could free themselves by an oath with compurgators. Our data show that, as well as in other regions of pre-modern Europe, the testimonies of the medical experts gained an increased importance in the judicial act, showing that the judicial authorities recognized the importance of the medical knowledge in the criminal process. Very few are the cases where the motif(s) of the criminal deeds can be clearly defined, but it is obvious that spousal infidelity, the aggressive nature of those implicated, alcohol abuse, the temporary presence of the soldiers in the town and the permanent presence of the domestic servants in the households of the citizens were of decisive influence on the cases.

\section{CRIMĂ ÎN FAMILIE. OMUCIDERI CONJUGALE ÎN CLUJUL PREMODERN}

\section{Cuvinte-cheie: epoca premodernă, agresiune conjugală, crimă/omucidere conjugală, otrăvire, urmărirea infractorilor}

Bazându-se pe datele protocoalelor de judecată și a socotelilor orașului dintre anii 15701660, lucrarea tratează tema omuciderilor conjugale din Clujul premodern. S-au păstrat șapte astfel de procese, iar în alte două dintre cazuri apare suspiciunea acestor infracțiuni. Numărul proceselor este relativ mic, lucru care ne îndeamnă să fim mai reținuți în concluzii. În trei cazuri arma letală a fost otrava, în două cazuri soția, iar într-un caz soțul fiind făptașul sau cel care a comandat fapta. În celelalte cazuri crimele au fost comise prin confruntare directă și deschisă, majoritatea făptașilor fiind bărbați. În șapte cazuri procesele au fost pornite din inițiativa proprie a orașului, de către cei doi directori (procurori) ai orașului. În privința statutului social al făptașilor exemplele arată că toate categoriile sociale ale Clujului premodern puteau fi implicate în astfel de cazuri, începând cu membri elitei până la iobagii din satele orașului. Cu toate că majoritatea cercetărilor arată că de regulă bărbații au comis astfel de fapte, în cazul nostru împărțirea făptașilor pe sexe arată o pondere aproape egală. În trei dintre cazuri în săvârșirea faptelor au fost implicați complici, aceștia fiind de fiecare dată bărbați aflați în relație intimă cu acuzatele. Cei găsiți vinovați au fost decapitați, însă în lipsa unor dovezi solide inculpații au scăpat de moarte prin jurământ cu cojurători. Datele arată totodată că, asemenea altor teritorii ale Europei premoderne, opinia experților medicali juca deja un rol destul de important în actul judecătoresc, ceea ce dovedește recunoașterea de către autorități a necesității folosirii cunoștințelor medicale în procesele penale. Foarte puține sunt acele cazuri în care mobilul faptelor poate fi delimitat cu precizie. Putem însă afirma, că infidelitatea conjugală, natura agresivă a celor implicați, consumul de alcool, soldații aflați în oraș precum și slujitorii care au trăit sub același acoperiș cu familiile orășenești au influențat în mod decisiv întâmplările. 